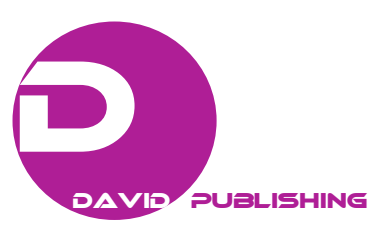

\title{
The Role of Science in Development of Water
}

\section{Management Profession in Serbia}

\author{
Jelena Velimirović \\ Faculty of Ecology and Environmental Protection, University Union Nikola Tesla, Belgrade 11000, Serbia
}

\begin{abstract}
The reintegration of water management, as an economic branch of special importance in the overall social and economic development of the country, is conditioned by appropriate scientific and technological progress. Water activities, whether water use, to protect against harmful effects of water or water protection, must be based on modern scientific achievements and modern technologies. Starting from the importance of water management, the Republic of Serbia in the past 40 years has provided certain support to basic and applied research in scientific disciplines within water management, energy, agriculture, construction, traffic and other branches. On the basis of these researches, new technology has been acquired, new technological processes have been developed, the technologies of design, construction and management of water management facilities and systems have been improved, devices and equipment have been developed, etc.. Scientific research work in the field of water management in Serbia took its place and was to a certain extent coordinated with the development policy of water management and other economic branches. However, it is evident that scientific and technological development did not follow the upward trend, development did not include water management as an economy branch as a whole, it was not based on the long-term water management development program and it did not have a continuous funding policy. Due to the lack of a long-term water management policy and the appropriate support (institutional and financial) for the implementation of this policy, scientific research in the field of water management has lost a step in relation to the developed countries of the world. Bearing in mind all the problems and plans for the development of water management, which are set out in the Water Management Plan of the Republic of Serbia, it is necessary to adopt a strategic plan for the development of water management, and within this framework, the strategic program of scientific research activities in the following period.
\end{abstract}

Key words: Science, scientific research, development, water management.

\section{Introduction}

The Water Management Basis of the Republic of Serbia is a basic document that determines the established strategy for water use, water protection and water protection in the territory of the Republic of Serbia [1]. The basic strategic goal of the Water Management Basis is defined by the law on waters as the following: maintenance and development of a water regime by providing the most favorable and best-performing technical, financial and ecological solutions for unified water management, protection against harmful effects of water, water protection and water use. The Water Management Basis of Serbia is tasked with ensuring the achievement of the

Corresponding author: Jelena Velimirović, M.Sc., research field: environmental protection. aforementioned basic strategic goal, taking into account often the interests of certain water management areas and branches, and to a large extent to the opposing requirements of other users of the premises.

In countries with weaker economic power, which, due to inadequate water prices, generally low standards and sometimes traditions, it is not possible to establish adequate water management. Also, very often, the status of water is not well known because of an inadequate or non-existent monitoring system. In addition, the competent state institutions are often insufficiently staffed and not adequately equipped; there is not enough inter-ministerial coordination.

It is necessary to develop awareness of the need to preserve the resources, both in terms of quality and 
quantity. Also, it is very important to increase the capacities of the state services related to the management of water resources, both in terms of the number of people involved in this field and their education in the field of integrated water management. It is also necessary to better equip institutions in technical terms (introduction of computers, information technologies, etc.) in order to implement new water management models, the need for professional and scientific capacity.

Bearing in mind the natural characteristics of the territory of Serbia, the spatial and temporal distribution of water resources and their users, as well as the mutual interaction of water use and water protection, water in the whole territory of Serbia must be integrated integrally, complexly and rationally.

In planning and implementing water management solutions, the need is implied for cooperation with other countries in order to bring the conditions of these waters into conditions in order to meet the future needs of these areas, to protect the water quality and to protect these areas from large waters.

When using water, the prescribed water regime must not be compromised (qualitative and quantitative compost), if endanger the health of people, endanger the animal and plant life, natural and cultural values and good (aesthetic values of water and environment, archaeological, historical, biological and geological resources), as well as the rational needs of downstream users and those interested in water.

Special attention should be given to revitalization and better use of existing irrigation systems. It is necessary to eliminate Serbia's lagging behind in this area in relation to all neighboring countries, considering that we have great spatial potentials in this area (water, land, temperatures, light, etc.). Future systems must be planned and used in a complex of integrated water management solutions. This should include protection from outside waters (flood protection), inland waterways (drainage), as well as all measures of hydrotechnical and agrotechnical reclamation [2].

From the unsatisfactory state of the quality of surface waters, the main goal of this segment of the Water Management Basis of Serbia is to provide elements of the strategy that will enable the reduction of pollution emissions and gradually bringing all sections of the watercourses to 2021 in the prescribed class.

\section{Multidisciplinary Research in Water Management}

In order to achieve the possible fulfillment of the commitments established by the Water Management Basis, it is necessary to provide a consistent system of water law norms, developed on the basis of the Constitution of the Republic of Serbia from 1990. It is important to bear in mind the fact that the Federal Republic of Yugoslavia was supposed to pass the Law on Water Management, in accordance with the Constitution of the Federal Republic of Yugoslavia, but even after the prolongation of the planned deadlines it was not done. In this respect, the question is whether it is still in force and whether the Law on Interrepublic and International Waters of 1974 is applicable. Namely, pursuant to article 12 of the Constitutional Law on the implementation of the Constitution of the Federal Republic of Yugoslavia (Official Gazette of the FRY No. 1/92), federal laws, including the Law on Inter-governmental and Interdependent Waters and other federal regulations, remain in force until they are harmonized with by the Constitution within the deadlines specified by the law.

The provisions of the act relate to current, spring, subterranean and interstate waters. All these issues were transferred to the Republic of Serbia's jurisdiction from the jurisdiction of the former federation by the Republic of Serbia Act of 1991. The Water Act of 1991, as lex specialis, is under preparation, unlike the federal law, which is not in use. Whether the discussion on the application of the 1974 Law on International and Intercontinental Water, at 
the time of validity and adoption of the 1991 law on the waters of the Republic of Serbia, requires a preliminary discussion on the content of the terms "basics of water regime" and "water regime"? How is the harmonization of the Constitution of the Republic of Serbia with the Constitution of the Federal Republic of Yugoslavia at this moment is primarily a political issue? Whose final outcome can not be known in advance in regulating and integrating republican regulations? It is very important that this area be regulated by clear regulations, and that there is a consistent institutional system in the country. Because the consequences of disordering, these areas or systemic incompatibilities can be catastrophic. The moment when a fund is established in the country's constitutional law, it will be possible to develop a concept that would include both federal and republic regulations.

Defining the fundamental transformational principles implies a clear definition of all elements within the relationships that are established in society on water, as a consumable (endangered) natural resource. State or public water management, which should be the same, from the population of governance, should be clearly defined and diversified at all levels, as well as the public interest. In 1945, the state nationalized the water management assets of numerous private water utilities. Relations between water management public corporations and other entities of the institutional water management system are regulated by water law regulations, while relations between water management public corporations and other entities of the legal system outside the circle of persons are covered by the concept of an institutional water management system, the application of general regulations.

As a separate segment of the institutional water management system, a system of organizations for supplying the population with water and drainage and wastewater treatment should be developed. It is about public services. The system should consist of sub-regional and regional public service organizations. In the course of their activities, these organizations would be linked to local autonomy bodies and water management public corporations. The Ministry of Water would be the highest hierarchical and functional. Executive authority is responsible for the management of the system of these organizations. The existence of this, in a functional sense of a unified, institutional water management system, enables the establishment, operation and development of various types of private and public entities, which would be profitable on water management, with full control of their impact on the water regime by the competent public water management corporations.

Scientific research on water management in Serbia comprises the steps of a gradual transition from fundamental research through the development of research to enlargement of the knowledge of the void and the legality of the process around the water to applied research in the implementation and practical application of solutions for the water utility and water management.

Science and scientific researches are of particular interest in the function of the water management in Serbia, such as hydrology, ecology, economics, agriculture, sociology, law, science of management and other scientific disciplines.

Hydrology is the void science, and its physical properties and formation circulation are in nature. Hydrological research is to better understand the concerns of water and the environment with feedback influence. The waterpower in Serbia used the research results contained in the explanation of the cycle in the hydrological measurements, predictions and statistics [3]. Hydrotechnical solutions in water management in Serbia are in order to find solutions:

(1) Reduction and predicting floods, landslides and droughts;

(2) Casualty and drinking water;

(3) Determination of networks and irrigation system; 
(4) Define the types of facilities for the provision of water supply and hydroelectric energy production [4];

(5) Foresight of geomorphological changes, such as the effects of erosion and deposition of sediments;

(6) Determination of the impact of economic and anthropogenic environmental changes on water resources;

(7) Determination of the type and intensity of the risks of pollution;

(8) Determination of the routes (roads) for transporting water.

Ecology provides a scientific explanation when using water causing damage to nature and environment. The specific objective of environmental protection is to prevent waste. Ecology present in the field of water is in scientific research of environmental abiotic factors (the physical and chemical environmental conditions) and biotic factors (influences that an organism suffering from other living beings). Research work in ecology water is related to establishing, preserving and ensuring a "good" water status [5].

The role of economics in water management is neglected or of no special theory. Under the influence of changes in ownership and control areas in the world and the development of environmental economics and economics of the public sector, economics of water management are gaining importance.

Its implementation requires defining the basic elements of value in the economy of water management. Establishing the economics of water management is based on the segments of water management system that applies to the disposal (use) water, water management services and other activities, and they are turning to water as a public good, services, as well as private goods and types of combinations of public private goods for common and collective use of water [6]. Water management is scientific research activities in the field of economy needed, because it will determine the theoretical rules of conduct and economic laws. Economics of water management is necessary to study in the field of water, water protection, use (exploitation) of water, especially the effects of water and water management of the environment, with the aim of developing the theory of economic assessments for decision-making on water in its "production" economic appropriation, possession and use.

Agricultural sciences are intensively offline in solving the problem of phenomena and events about water and water management in the areas of soil science of geology, agrochemicals, plant protection, irrigation, drainage, soil conservation and water use in crop production, horticulture and viticulture, and in particular in the agricultural economy [7].

Sociological science in water management is based on research in the social demographics, the theory of social structures and systems, sociology of work, settlements, economic sociology and others.

Legal science in water management is involved in the development of general administrative law, administrative management, ownership and property rights, the development of the political system, financial law, labor law and others.

Contemporary (strategic) management as a separate discipline can accelerate the development of water resources through the multidisciplinary operation in research on water management and water management systems.

\section{Application of Science and Scientific Research in Serbian Water Management}

The direction of science and scientific research work in the water sector in Serbia is determined by water management problems that require new knowledge on water management areas and its development. Contents of scientific research related to:

(1) Ambition for research related to technical, economic and legal characteristics of the water problems with the use of scientific methods;

(2) Identify areas and branches of research; 
(3) Empirical and theoretical solving problems and creating conditions for the implementation of solutions;

(4) Application of domestic and foreign achievements in the field of water management and branches;

(5) Science research approach to determine the hypothesis;

(6) Develop hypotheses and research needed to be done about the situation, elements and events around the water system and for a specific time and space;

(7) Determination of criteria feasibility research, theoretical value and practical significance;

(8) Value determination problems and solutions through the verifiability of success.

Due to scientific research, the development of water management in Serbia, acquirement of new knowledge, application of technological processes and technology were developed in the design, construction and operation of water facilities and systems. Events in the past, without a strategy for the development of scientific research in the water sector have led to a loss of continuity in relation to the European and world scientific achievements.

Examples of well-applied scientific research papers are guaranteed determining environmental rate [8] and the planning of water management systems [9].

Research that contributes to the development of water management in Serbia refers to the science of engagement required for the implementation of the following [1]:

(1) Management of river basin;

(2) Integrally and integrated management of water resources;

(3) Protection of water (of surface and ground);

(4) Use water in water supply;

(5) Arrangement of water courses and protection against harmful effects of water;

(6) Use hydropower;

(7) Hydraulic engineering land reclamation;

(8) Application of modern technology;
(9) Advancement methods and technology research, design, construction, maintenance and operation of facilities and systems;

(10) Define the economic fundamentals, instruments and measures in the areas of water management in the state and economic structure;

(11) Influential factors for water management surroundings and environment;

(12) Develop legislature and normative activities;

(13) Systematizing technical, legal and economic elements and factors in interstate and international relations in water management and water management systems.

\section{Water Management Branches}

Water management profession in the professional skills of the term education and skills to practical work achieved a positive result. In water management, there is a huge range of complexity of the simplest tasks, such as performing. The history of the water management profession has demonstrated a high level of knowledge and skills for the stable operation of the system, specially in situations of problems in floods, droughts, pollution or when water is lacking. In the last decades, it has weakened the waist which has become a special problem of water management. The water management profession created the experience of solving problems. It is passed from generation to generations of fluctuations and the departure of employees without transfer of knowledge and skills. And new employees are not passing through the theoretical and practical tranining.

Different professions create the basis for determining the causes of traffic and the status of water, and for proposing services to obtain benefits. Results are measured in technical and economic impacts, particularly impacts on the population and industries of the economy.

Waist in water management is addressed in the environment where the structural, social, economic and technological changes force the innovation of 
knowledge and skills. In particular, the views from the environment, constantly monitor the results of the water management profession and indicate good or bad actions taken.

Water management profession makes a collection of different professions who seek to build consistent internal relations. Profession in the system attempts to build a harmonious interior relations. In the system of water management (water resources), each other's values and integration will be respected.

Integrating some pike is to strengthen the position and interests of water management, which is achieved by a close appreciation of knowledge, skills and the way they execute in joint activities. It is especially necessary rapprochement of certain professions in water management profession, because the interests of certain professions and individual goals are converted into a common goal in a particular workplace behavior functional organization. Organization by the water management must limit activities of representatives of certain professions that seem disintegration, with the introduction of proportionality in remuneration, according to the intensity of the impact of certain professions in achieving the objectives. It is also important to develop information and communication between the waist of certain essential events for the creation and improvement of working conditions. In future profession in operation management it should find an adequate alternative solution to the problem in a situation where classical method can not be achieved. For the profession, it is necessary to use modern technical and technological resources, new knowledge and skills in the operation.

\section{Conclusions}

The role of science and scientific research in water sector in Serbia has so far yielded excellent results, and the application has been removed of harmful effects of water, like water pollution. Necessarily, approach changes, in management of water in the educational and research institutions, have contributed to the development of water management profession. The lessons learned from the study is that employees are interactive, posing new tasks for arriving at scientific research to improve the profession which have a common influence on the efficiency of water management. This sustainable management of water management requires a multidisciplinary and skill development of human resource.

\section{References}

[1] Serbia Ministry of Agriculture, Forestry and Water Management. 2001. "Water Management Basis of the Republic of Serbia." Institute for Water Management “Jaroslav Černi”, Belgrade. Accessed June 2001. http://www.srbijavode.rs/Data/Files/vodoprivredna_osno va_republike_srbije.pdf.

[2] Dimkić, M., Kovačević, S., and Vasiljević, B. "Basic Principles of Water Management." Internal Skript I Part. University of Novi Sad, Faculty of Technical Sciences. http://www.izzs.uns.ac.rs/images/stories/nastavni_materij al/osnovni_principi_upravljanja_vodama/skripta_prvi_ko lokvijjum.pdf.

[3] European Communities. 2004. Common Implementation Strategy-Guidances.

[4] Udovičić, B. 2004. "The Energy System in Globalization and the Free Market." In Insupportability of Sustainable Development. Zagreb, Croatia: Kigen.

[5] Bajčetić, M. 2010. Value System of Water Management.

[6] Bajčetić, M. 2008. Water Management Economy in the Private and Public Sector Partnership. Novi Sad, Serbia: Prometej.

[7] Cvijanović, D. 2010. "Education, Scientific-Research and Consulting Work in Agriculture of Serbia." In Applied Studies in Agribusiness and Commerce. Budapest: Agroinform Publishing House, 11-8.

[8] Djordjević, B., and Dašić, T. 2011. "Determining the Necessary Flows Downstream of Dams and River Water Catchment.” Journal of Water Management 43: 151-64.

[9] Djordjević, B., and Dašić, T. 2016. "Categories of Reliability to Be Tested by the Planning and Use of Water Supply Systems.” Journal of Water Management 48: 29-44. 